2014-01-01

\title{
Deformation and magnetic fabrics in ductile shear zones: A review
}

Ferre, EC

http://hdl.handle.net/10026.1/8615

10.1016/j.tecto.2014.04.008

Tectonophysics

All content in PEARL is protected by copyright law. Author manuscripts are made available in accordance with publisher policies. Please cite only the published version using the details provided on the item record or document. In the absence of an open licence (e.g. Creative Commons), permissions for further reuse of content should be sought from the publisher or author. 


\title{
Deformation and magnetic fabrics in ductile shear zones: A review
}

\author{
Eric C. Ferré ${ }^{\mathrm{a}, *}$, Aude Gébelin ${ }^{\mathrm{b}}$, Jessica L. Till ${ }^{\mathrm{c}}$, Caroline Sassier ${ }^{\mathrm{d}}$, Kurtis C. Burmeister ${ }^{\mathrm{e}}$ \\ a Department of Geology, Southern Illinois University, Carbondale, IL 62901-4324, USA \\ b Biodiversity and Climate Research Center (BiK-F), Frankfurt/Main, Germany \\ c Institut de Minéralogie et de Physique des Milieux Condensés, UMR 7590, Université Paris 6 Pierre and Marie Curie, 4 place Jussieu, 75005 Paris, France \\ ${ }^{d}$ Department of Geosciences, University of Oslo, P.O. Box 1047 Blindern, N-0316 Oslo, Norway \\ e Department of Earth \& Environmental Science, University of the Pacific, 3601 Pacific Avenue, Stockton, CA 95211, USA
}

\section{A R T I C L E I N F O}

\section{Article history:}

Received 5 November 2013

Received in revised form 2 April 2014

Accepted 6 April 2014

Available online 15 April 2014

\section{Keywords:}

Mylonite

Microstructure

Anisotropy of magnetic susceptibility

Shear zone

\begin{abstract}
A B S T R A C T
The Anisotropy of Magnetic Susceptibility (AMS) is a well-established petrofabric tool for indicating relative strain and microstructural character and has been validated on various rock types and different structural settings. The magnetic susceptibility of a rock $(K)$ depends primarily on the nature and abundance of magnetic minerals. The physical arrangement and lattice-preferred orientation of these magnetic minerals give rise to magnetic anisotropy. The AMS scalar parameters most commonly used to constrain strain include the corrected degree of anisotropy $\left(P^{\prime}>1\right)$, a proxy for fabric intensity, and the shape factor $(-1 \leq T \leq+1)$, an indicator of the magnetic fabric symmetry (prolate vs. oblate).

A number of studies have shown that a positive correlation generally exists between $P^{\prime}$ and strain. Thus, the AMS shows a great potential as a tool for examining deformation in geologic structures characterized by large strain gradients such as shear zones. However, a number of caveats exist: (i) The increase of $P^{\prime}$ with strain cannot be solely attributed to deformation because $P^{\prime}$ also increases with $K$ regardless of deformation; (ii) Strain across shear zones is typically heterogeneous and is often localized in units of different lithology, thus making the separation of the lithological and strain controls on AMS difficult; also, deformation is commonly accompanied by mineral segregation or fluid-rock interaction that induces changes in magnetic mineralogy; (iii) Even if the undeformed lithology was uniform across a shear zone, variations in strain rate or temperature may result in different deformation mechanisms; hence, the relationship between $P^{\prime}$ and strain depends strongly on both the mineral carriers of AMS and on deformation mechanisms; and (iv) The AMS is unable to resolve composite fabrics, such as those resulting from S-C structures, where minerals on the C and S planes, respectively, contribute to AMS.
\end{abstract}

(c) 2014 Elsevier B.V. All rights reserved.

\section{Introduction}

The anisotropy of magnetic susceptibility (AMS) provides rapid information about the petrofabric of deformed rocks (e.g., Tarling and Hrouda, 1993). Initially promoted by Graham (1954), this method became increasingly popular from the 1960's through the 1980's (Graham, 1966; Granar, 1958; Hrouda, 1982; Kligfield et al., 1977; Owens and Bamford, 1976; Owens and Rutter, 1978; Rathore et al., 1983; Singh et al., 1975; Stacey, 1960; Stone, 1963; Tarling, 1971). Graham Borradaile's role in establishing the validity and applications of AMS stands as one of the most influential contributions to rock magnetism (Borradaile, 1987, 1988, 1991, 1993; Borradaile and Alford, 1987, 1988; Borradaile and Henry, 1997; Borradaile and Jackson, 2004, 2010; Borradaile and Mothersill, 1989). Numerous studies

\footnotetext{
* Corresponding author.

E-mail address: eferre@geo.siu.edu (E.C. Ferré).
}

now routinely use the AMS method to constrain strain in geological materials as varied as migmatite, granite, mylonite, volcanic glass, pseudotachylyte, glacial till or glacier ice (e.g., Cañón-Tapia, 2004; Fleming et al., 2013; Gébelin et al., 2006; Gentoso et al., 2012; Kruckenberg et al., 2011; Mamtani et al., 2011; Molina Garza et al., 2009; Richter et al., 1993; Sidman et al., 2005). Growing interest in AMS as a proxy for strain justifies reviewing the relationship between magnetic anisotropy and deformation, particularly in ductile shear zones.

Ductile shear zones constitute planar domains characterized by strongly localized deformation (Fig. 1). They occur in various tectonic settings: extensional (e.g., Bitterroot shear zone, Montana; Foster et al., 2001; Sidman et al., 2005), strike-slip (e.g., Ailao Shan-Red River shear zone, China; Leloup et al., 1995; Zhou et al., 2002), and compressional (e.g., Moine thrust, Scotland; Law et al., 1984; Torsvik and Sturt, 1988). Shear strain $(\gamma)$ describes the amount of deformation recorded in rocks within the shear zone. Strain rate $(\dot{\varepsilon})$ defines the amount of strain localization per time unit $\left(10^{-13} \mathrm{~s}^{-1}<\dot{\varepsilon}<10^{-15} \mathrm{~s}^{-1}\right.$; Pfiffner 

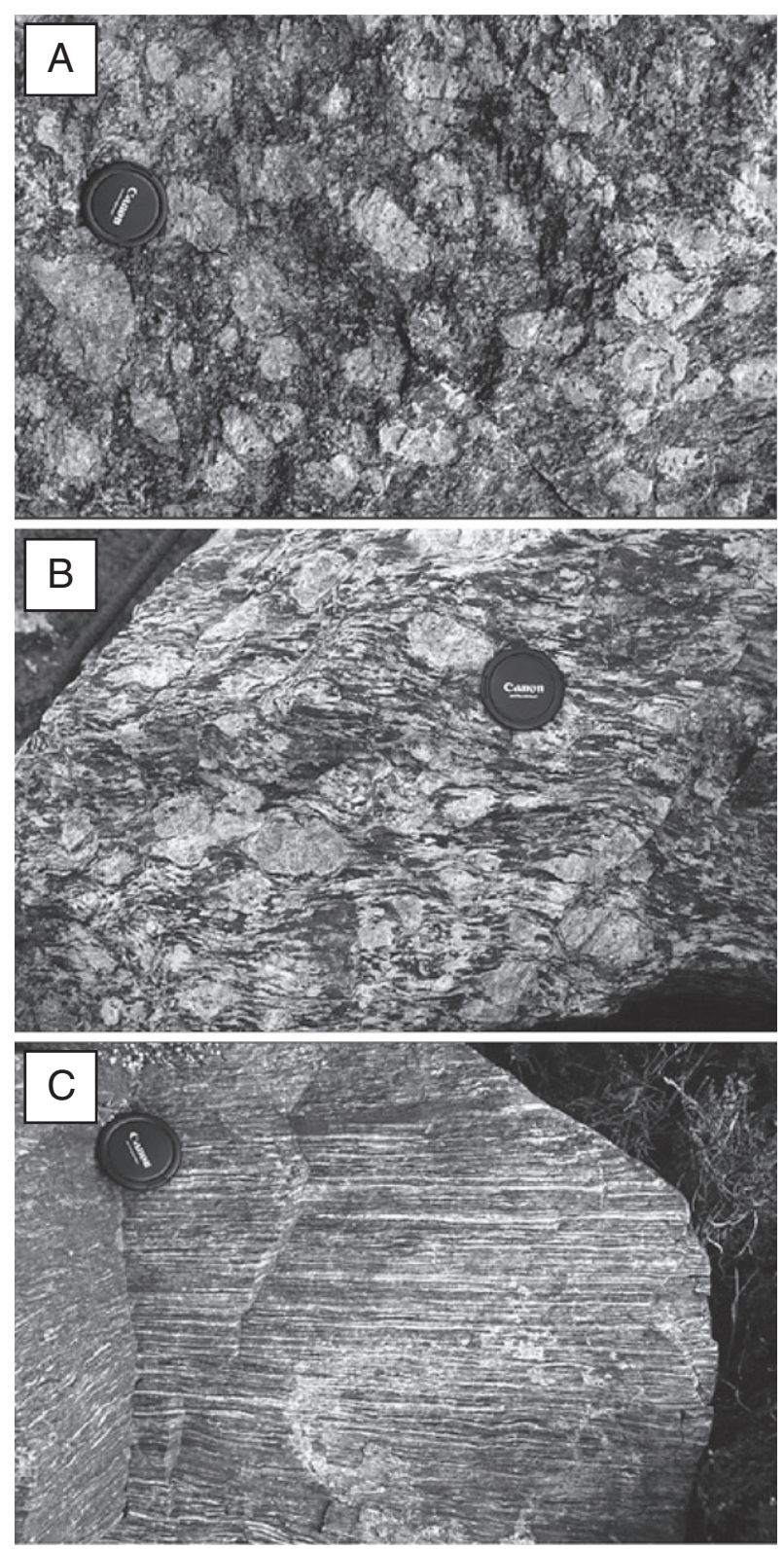

Fig. 1. Increasing deformation across a shear zone, Flatracket gneiss, Norway (courtesy Brad Hacker).

and Ramsay, 1982; Sassier et al., 2009). Significant variation in strain rate may occur within a single shear zone, highlighting the importance of strain localization (Boutonnet et al., 2013). Rocks deforming in ductile shear zones commonly undergo grain-size reduction, a process that decreases the mechanical strength of rocks (Hobbs et al., 1990; Poirier, 1980), and thus further localizes deformation.

A fundamental correlation between finite strain and magnetic anisotropy has often been proposed (Fig. 2; e.g., Benn, 1994; Borradaile; 1987, 1988; Cogne and Perroud, 1988; Henry and Daly, 1983; Hirt et al., 1993; Housen et al., 1995; Hrouda, 1987, 1993; Kligfield et al., 1977, 1981; Kontny et al., 2012; Lüneburg et al., 1999; Plissart et al., 2012; Rathore, 1979; Tikoff et al., 2005; Tripathy et al., 2009). This correlation would apply to both the magnitude of strain and magnetic anisotropy, and to the principal directions of the strain and magnetic anisotropy tensors. Determining finite strain in shear zones requires knowledge of undeformed rock fabrics outside the shear zone (e.g., Borradaile and Alford, 1987; Burmeister et al., 2009; Goldstein, 1980; Hrouda and Janak, 1976), unless one assumes the initial fabric is
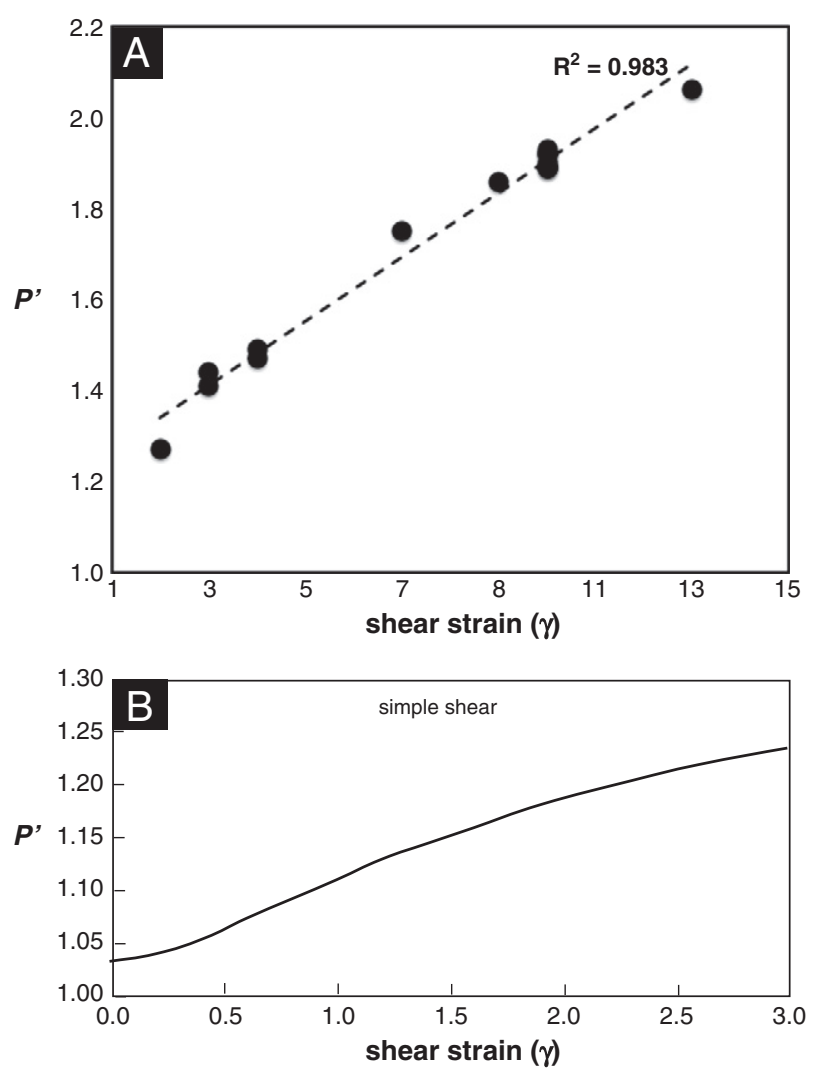

Fig. 2. A. Example of a natural ductile shear zone showing the correlation between $P^{\prime}$ and shear strain (data from Housen et al., 1995). B. Numerical simulation of the variation of the degree of magnetic anisotropy $\left(P^{\prime}\right)$ of the AMS ellipsoid with increasing strain $(\gamma)$ for simple shear (after Benn, 1994). Note that the variation is non-linear.

isotropic. However, several factors may complicate the relationship between AMS and finite strain in ductile shear zones.

First, deformation promotes static and dynamic recrystallization, which may modify the orientation of magnetic grains and/or their lattices after deformation. Deformation also enhances metamorphic reactions by allowing fluids into high-strain domains such as shear zones (e.g., Mertanen and Karell, 2012). Consequently, mineral assemblages in shear zones tend to differ from the assemblages in the surrounding undeformed host rock (e.g., Ferré et al., 1997). Reciprocally, any preexisting lithological heterogeneity may localize deformation and lead to shear zone development (e.g., Sidman et al., 2005).

Second, ferromagnetic and paramagnetic minerals control AMS while the role played by diamagnetic minerals in AMS generally is negligible (e.g., Martin-Hernandez and Ferré, 2007; Rochette, 1987). Populations of ferromagnetic (s.l.) grains in rocks typically display a shapepreferred orientation (SPO) responsible for a magnetostatic anisotropy (Borradaile and Jackson, 2004; Tarling and Hrouda, 1993). Ferromagnetic (s.l.) grains may also show a distribution anisotropy caused by interactions when grains are closer to each other than their own diameter (Grégoire et al., 1998; Hargraves et al., 1991; Stephenson, 1994). In addition, ferromagnetic (s.l.) and paramagnetic grains may exhibit a lattice-preferred orientation (LPO) resulting in a magnetocrystalline anisotropy (e.g., Tarling and Hrouda, 1993; Vergne and Fernandez, 1990).

Third, magnetic anisotropy depends on the deformation mechanism(s) that generate the fabric of AMS carriers, under various strain rates, temperatures and differential stresses (e.g., Housen et al., 1995; Till and Moskowitz, 2013; Till et al., 2012). Strain partitioning at various scales also causes complications with the analysis of strain through magnetic methods (Evans et al., 2003; Kankeu et al., 2012; Till and Moskowitz, 2013). Indeed, shear zones commonly contain domains of high- and low-strain as a result of lithological differences 
(e.g., Schulmann et al., 2009; Zavada et al., 2009). Similarly, strain can be partitioned by viscosity contrast between AMS carriers and their matrix (e.g., Till and Moskowitz, 2013). Finally, the orientations of the principal strain axes in a shear zone depend on the strain regime (Goodwin and Tikoff, 2002; Tikoff and Teyssier, 1994), and therefore the AMS hinges on the vorticity of deformation.

In this paper, we discuss several factors controlling the development of an anisotropy of magnetic susceptibility in ductile shear zones.

\section{Anisotropy of magnetic susceptibility and anisotropy parameters}

The magnetic susceptibility, $K$ (dimensionless) is the ratio of the induced magnetization, i.e., the magnetic moment per unit volume, $M$ (in $\mathrm{A} / \mathrm{m}$ ), to the inducing magnetic field strength, $H$ (in $\mathrm{A} / \mathrm{m}$ ).

$K=M / H$

In polymineralic rocks, $K$ is the sum of the magnetic susceptibilities of all rock-forming minerals, including diamagnetic, paramagnetic or ferromagnetic (s.l.) species,

$K=\Sigma_{\mathrm{i}} K_{\mathrm{i}} \cdot C_{\mathrm{i}}$

where $K_{\mathrm{i}}$ is the intrinsic magnetic susceptibility of each mineral species, and $C_{\mathrm{i}}$ is the concentration of this species.

In most rocks the magnetic susceptibility is anisotropic, i.e., it varies with the direction of the inducing field with respect to the rock. This anisotropy is caused by a combination of the preferred orientation of grains, mineral grain distribution or their lattice-preferred orientation, and the intrinsic anisotropy of the grains (shape or crystalline anisotropy). The AMS, commonly idealized as a symmetric second rank tensor, is represented as an ellipsoid with three mutually perpendicular principal axes, $K_{1}, K_{2}$, and $K_{3}$, along which the magnetic susceptibility has the eigenvalues $K_{1} \geq K_{2} \geq K_{3}$. The AMS measurement procedures are described in Collinson et al. (1967) and Tarling and Hrouda (1993). The degree of anisotropy of the ellipsoid can be described by the corrected anisotropy degree $P^{\prime}$ (Jelinek, 1981).

$P^{\prime}=\exp \sqrt{2 \sum\left(\ln K_{\mathrm{i}}-\ln K_{\mathrm{m}}\right)^{2}}$

where $\mathrm{i}=1$ to 3 , and $K_{\mathrm{m}}$ is the arithmetic mean susceptibility.

$P^{\prime}$ is a measure of the degree to which the AMS ellipsoid deviates from a sphere. In rocks having no preferred orientation of minerals the degree of anisotropy is equal to 1.

The shape of the AMS ellipsoid, described by the parameter T, can vary from oblate, for $0 \leq \mathrm{T} \leq 1$, to prolate, for $-1 \leq \mathrm{T} \leq 0$.

$\mathrm{T}=\left[\left(2 \ln K_{2}-\ln K_{1}-\ln K_{3}\right) /\left(\ln K_{1}-\ln K_{3}\right)\right]$

\section{Relationship between finite strain and AMS tensors}

The AMS of a rock arises primarily from the SPO and LPO of magnetic grains (Borradaile, 2001; Borradaile and Jackson, 2004; Tarling and Hrouda, 1993). Since deformation affects SPO and LPO, it influences the magnitude and orientation of the AMS. Numerous studies demonstrate that the principal AMS axes, $K_{1}, K_{2}$, and $K_{3}$, coincide respectively with the finite strain axes, X, Y, and Z (e.g., Borradaile, 1991; Borradaile and Tarling, 1981; Rathore, 1979). However, the coaxiality between the two tensors holds true only if the magnetic axes of the dominant AMS carrier correspond to the axes of its shape anisotropy. When the AMS axes and morphological/crystallographic axes coincide, which is the case of most common minerals, the magnetic fabric is deemed "normal". This relationship holds true for multidomain (MD) magnetite (e.g., Borradaile and Jackson, 2004) and for most common phyllosilicates (e.g., Borradaile and Werner, 1994; Dunlop et al., 2006; Martı́n-Hernández and Hirt, 2003). In this case, $K_{1}$ constitutes the magnetic lineation and $K_{3}$ the pole to the magnetic foliation.

"Inverse" magnetic fabrics occur when $K_{1}$ corresponds to $\mathrm{Z}$ and $K_{3}$ to X, a configuration observed with certain paramagnetic and ferromagnetic minerals. For example, single-domain (SD) magnetite or maghemite grains exhibit the largest magnetic susceptibility perpendicularly to their short axis (Borradaile and Puumala, 1989; Potter and Stephenson, 1988; Rochette et al., 1992), resulting in an inverse magnetic fabric. Other minerals, such as tourmaline, cordierite and goethite, exhibit a magnetocrystalline anisotropy characterized by an inverse magnetic fabric (Ferré and Améglio, 2000; Rochette et al., 1992, 1994). Similarly, iron-bearing carbonates, such as siderite, ankerite, and ironrich $(\mathrm{FeO}>1 \%)$ calcite or dolomite, may produce inverse fabrics (Ellwood Brooks et al., 1986; Hirt and Gehring, 1991; Ihmlé et al., 1989; Rochette, 1988; Winkler et al., 1996).

Undeformed rocks may exhibit a primary AMS acquired during rock forming processes. For example, pristine sedimentary rocks commonly exhibit a planar magnetic fabric due to the preferred orientation associated with the deposition and compaction of clasts deposited at the bottom of the depositional environment (e.g., Cifelli et al., 2009; Hrouda and Janak, 1976; Parés, 2004; Parés et al., 1999) and, in some cases, a linear fabric caused by the hydrodynamic sorting of sediments (e.g., Anchuela et al., 2012). Similarly, magmatic rocks may display a planar magnetic fabric resulting from crystal settling in a magma chamber and a linear magnetic fabric due to viscous magmatic flow (e.g., Hrouda et al., 2005; Loock et al., 2008; Zavada et al., 2009). Isolating the magnetic fabric of tectonic origin from the primary magnetic fabric requires subtracting the undeformed AMS tensor from the bulk AMS tensor (e.g., Borradaile and Alford, 1987; Burmeister et al., 2009; Goldstein, 1980; Goldstein and Brown, 1988). This approach remains sensitive to measurement precision (Hirt and Almqvist, 2013; Hrouda et al., 2000). Finally, experiments have consistently shown that analog materials tend to exhibit a primary AMS in the absence of deformation (Arbaret et al., 1996, 1997, 2000; Borradaile and Alford, 1987; Borradaile and Puumala, 1989), underscoring that not all magnetic anisotropy is associated with the accumulation of strain.

In ductile shear zones, the main deformation mechanisms depend primarily on strain rate, temperature, and differential stress. The specific deformation mechanism responsible for the correlation between AMS and finite strain depends on the mineralogical source of the AMS (e.g., Borradaile and Alford, 1988; Housen et al., 1995; Parés and van der Pluijm, 2002). The most common mechanisms deforming magnetic minerals in a ductile shear zone include (e.g., Sidman et al., 2005): (i) grain rotation; (ii) recrystallization, and (iii) plastic deformation. In turn, the mineralogical source of AMS determines the type of magnetic anisotropy (magnetostatic, magnetocrystalline, or distribution). In the following sections, we discuss the relationship between magnetic anisotropy $\left(P^{\prime}\right)$ and magnetic susceptibility $(K)$ and how deformation mechanisms and the type of magnetic anisotropy affect the relationship between shear strain and AMS.

\section{Mineralogical sources of the AMS in shear zones}

The most abundant rock-forming minerals (calcite, quartz, feldspar) are typically diamagnetic and exhibit weak magnetic susceptibility. However, diamagnetic AMS fabrics can be measured in the absence of significant Fe-bearing phases (de Wall et al., 2000). Fe-bearing silicates may significantly contribute to the paramagnetic component of AMS, and in these minerals, the direction of maximum magnetic susceptibility generally coincides with the long axis of the grain. However, this is not the case for monoclinic and triclinic minerals due to their non-orthogonal crystallographic axes which cannot geometrically coincide with AMS axes, being by definition mutually perpendicular (Borradaile and Jackson, 2004; Lagroix and Borradaile, 2000). The Fe content and crystalline symmetry of pure paramagnetic minerals 
control their magnetic anisotropy (Belley et al., 2009; Borradaile and Werner, 1994; Hunt et al., 1995).

For minerals with magnetic ordering, grain-scale anisotropy is primarily produced by magnetocrystalline anisotropy and shape anisotropy. For non-cubic, antiferromagnetic, or low susceptibility magnetic minerals, such as ilmenite, pyrrhotite, and hematite, shape anisotropy is generally negligible and magnetocrystalline anisotropy tends to dominate. Thus the grain-scale AMS is controlled largely by the crystallographic orientation of the minerals. For high-susceptibility cubic Fe-oxides, non-isotropic shapes give rise to a demagnetizing factor, $N$, and the grain AMS is largely controlled by the shape anisotropy. The degree of AMS in a single grain with shape-controlled anisotropy is given by Uyeda et al. (1963):

$P=\frac{1+\kappa_{\mathrm{i}} N_{a}}{1+\kappa_{\mathrm{i}} N_{b}}$

where $\kappa_{\mathrm{i}}$ is the intrinsic susceptibility and $N_{a}$ and $N_{b}$ are the demagnetizing factors along the maximum and minimum grain dimensions, respectively. $N$ values for variously shaped ellipsoids can be calculated from equations given by Osborn (1945). It is clear that grain-scale AMS intensity depends strongly on the intrinsic susceptibility, since $P$ goes to 1 as $\kappa_{\mathrm{i}}$ decreases (Fig. 3). The relationship between intrinsic susceptibility and measured bulk susceptibility, $\kappa_{0}$, is given by Uyeda et al. (1963).

$\kappa_{0}=\frac{\kappa_{\mathrm{i}}}{1+N \kappa_{\mathrm{i}}}$

Very few methods exist for measuring $\kappa_{\mathrm{i}}$ in a bulk specimen, although several studies (Dunlop, 1984; Hodych, 1986; Stacey and Banerjee, 1974) have observed that it generally varies inversely with coercivity, $H_{c}$, as: $\kappa_{\mathrm{i}} \approx A / H_{c}$, where $A$ is a proportionality constant. Hrouda (1993) reported $\kappa_{\mathrm{i}}$ values between 6 and 21 [SI] from published estimates for MD magnetite, while Jackson et al. (1998) calculated values as high as 61 for large MD grains of nearly pure magnetite. For magnetite, Stacey and Banerjee (1974) suggest a proportionality constant of 56.25 [SI], however, Hodych (1986) argues that $A$ may vary substantially from one rock to another and determined $A$ values between 32.5 and 89.75 [SI] for a variety of rocks containing PSD to MD-sized magnetite. Similarly to coercivity, $\kappa_{\mathrm{i}}$ varies in magnetic particles with grain size (Stacey and Banerjee, 1974), composition (O'Reilly, 1984) and the internal stress state or defect concentration in the particles (Liu et al., 2008). $\kappa_{i}$ of magnetic particles in a rock may evolve during deformation if any changes in the above variables occur. Thus, physical changes that occur during deformation, such as grain size reduction or stress-

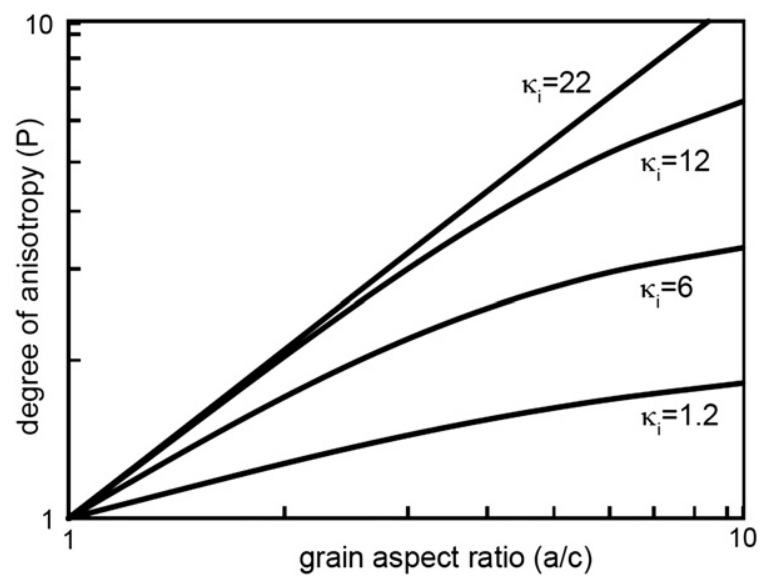

Fig. 3. Variation of the degree of magnetic anisotropy $(P)$ for magnetic particles shaped as prolate ellipsoids for varying aspect ratios and intrinsic susceptibilities after Uyeda et al. (1963). $\kappa_{\mathrm{i}}$ refers to intrinsic magnetic susceptibility. P shows a strong dependence to the intrinsic susceptibility, where $P$ goes to 1 as $\kappa_{\mathrm{i}}$ decreases. induced defects that increase coercivity (Jackson et al., 1993), will tend to decrease the AMS of magnetic grains.

Theoretical calculations of AMS development as a function of strain are generally categorized into four types of strain response, depending on whether the particles carrying the AMS undergo internal deformation or rotate as rigid particles. The passive model (Owens, 1974) describes magnetic grains deforming identically to the matrix, so that the mean magnetic grain shape approximates that of the strain ellipsoid. The ductile model (Hrouda and Lanza, 1989) also describes magnetic grains deforming internally but at a lower rate than the matrix, where the AMS strength as a function of strain depends on the viscosity contrast or degree of strain partitioning between the magnetic particle and matrix. The line/plane and viscous models (Owens, 1974) both describe rigid rotation with the difference that in the viscous model, lowaspect ratio grains are allowed to rotate through the shear plane for simple shear strain, leading to oscillating fabric intensity with increasing strain (Arbaret et al., 2000; Hrouda, 1993). For grains with aspect ratios greater than about 5 , the line/plane and viscous models can be regarded as equivalent (Hrouda, 1993). More complex models accounting for physical interaction between particles during rotation have also been developed (Arbaret et al., 2000). In rigid rotation models, the maximum AMS intensity that can develop during deformation is controlled by the intrinsic magnetic anisotropy of the individual grains.

Shear zones are typically areas of high fluid flow which enhances metamorphic reactions, and contributes to the development of a shear zone-specific magnetic mineralogy (e.g., Aranguren et al., 1996; Aubourg et al., 2000; Housen et al., 1995). The Parry Sound shear zone is a clear example of such reactions (Housen et al., 1995). The common occurrence of goethite $(\alpha \mathrm{FeO} \cdot \mathrm{OH})$ in numerous shear zones suggests that primary ferromagnesian silicates (hornblende, biotite) or primary oxides (magnetite) might have been destabilized during fluid-present mylonitization. Deformation also promotes recrystallization which, in turn, may lead to significant mineralogical changes within the shear zone. Each mineralogical component of the AMS fabric has its own magnetic anisotropy relationship to strain. In addition, even in the rare cases where the magnetic mineralogy remains constant throughout a shear zone, changes in strain rate and in grain size are likely to cause deformation to affect the protolith with distinct deformation mechanisms.

Finally, the variations of the corrected degree of magnetic anisotropy $P^{\prime}$ with magnetic susceptibility $K$ in plutonic rocks are particularly significant because these rocks tend to be compositionally homogeneous and weakly deformed. In most cases, $P^{\prime}$ increases with $K$, regardless of strain (e.g., Bouchez, 1997; Ferré et al., 1997, 1999; Ferré and Améglio, 2000). A similar increase may occur in volcanic rocks but has not yet been well documented. An increase in concentration of ferromagnetic grains would statistically decrease the distance between interacting grains, therefore it would promote distribution anisotropy, a source of AMS discussed by Hargraves et al. (1991). However, since we observe this $P^{\prime}-K$ correlation both in ferromagnetic and paramagnetic intrusives (Fig. 4), an alternative explanation is required. The viscosity of a silicate melt increases with increasing silica content and decreases slightly with increasing iron content (Giordano et al., 2008). It follows that mafic magmas overall display lower viscosities than their felsic counterparts. We therefore suggest that low-viscosity magmas, typically characterized by high $\mathrm{FeO}(\mathrm{T}$ ) and high $K$ (Aydin et al., 2007; Ferré et al., 2012; Gleizes et al., 1993), would record higher shear strain and lead to higher degrees of magnetic anisotropy $P^{\prime}$.

\section{AMS and deformation mechanisms}

A sound interpretation of AMS requires a minimal understanding of active deformation mechanisms (Housen and van der Pluijm, 1990). Most investigations of deformation mechanisms and magnetic fabrics in natural shear zones concern medium- $\left(400 \pm 50{ }^{\circ} \mathrm{C}\right)$ to hightemperature $\left(>500{ }^{\circ} \mathrm{C}\right)$ shear zones in which plastic deformation took place under strain rates between $10^{-12}$ and $10^{-15} \mathrm{~s}^{-1}$ and deviatoric 


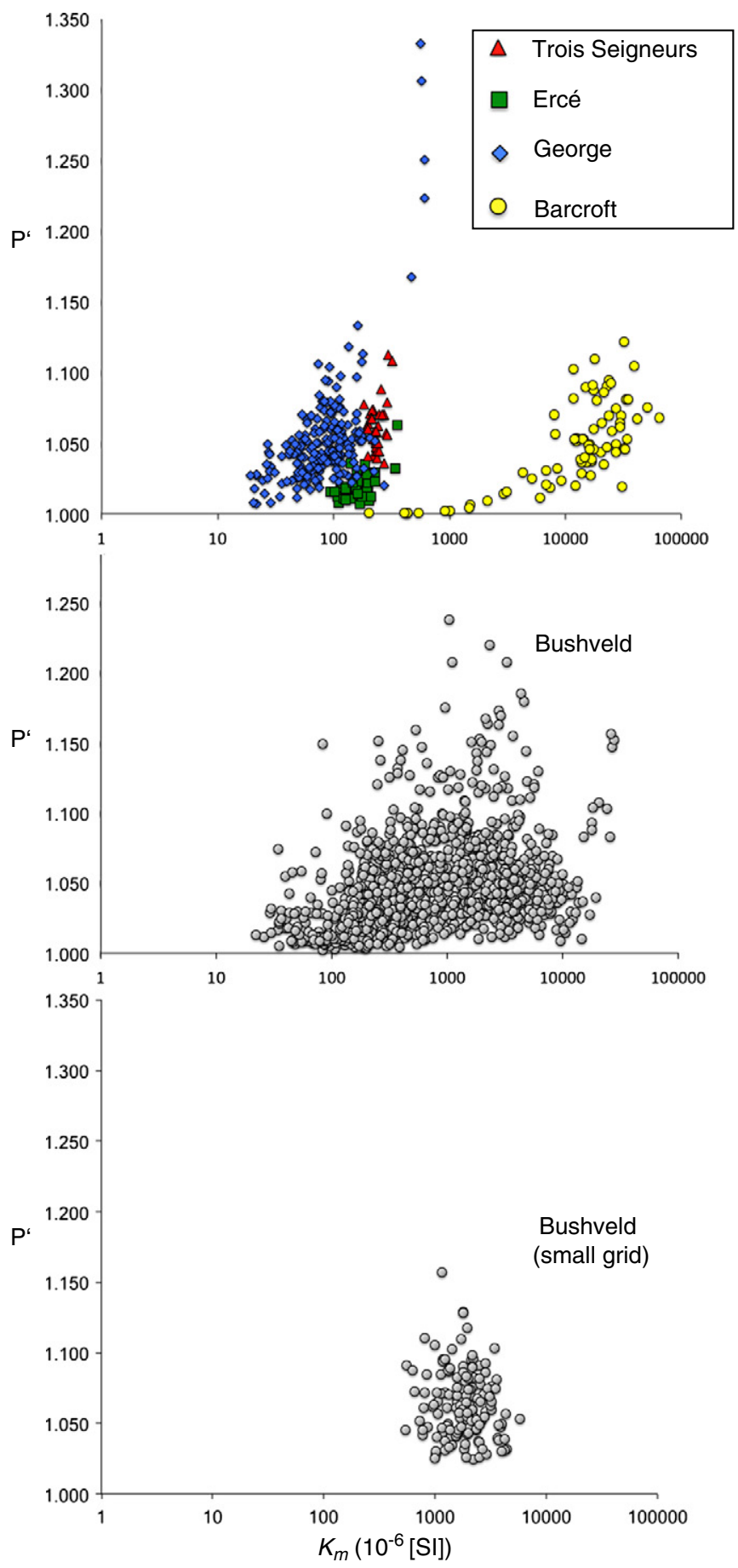

Fig. 4. $P^{\prime}-K_{m}$ correlation both in ferromagnetic and paramagnetic intrusives. Top: The Trois Seigneur (Leblanc et al., 1996), Ercé (Gleizes, 1992) and George (Ferré and Améglio, 2000) paramagnetic granites display a positive, non-linear increase of $P^{\prime}$ with $\mathrm{K}_{\mathrm{m}}$. The Barcroft ferromagnetic pluton (Ferré et al., 2012) displays a similar variation. The $P^{\prime}-K$ correlation occurs both in ferromagnetic and paramagnetic granites. Middle: The Bushveld ferromagnetic granites are considered anorogenic and weakly deformed. At the scale of several tens of kilometers of exposure (Ferré et al., 1999; Wilson et al., 2000), the regional increase in magmatic shear strain results from a higher $\mathrm{FeO}(\mathrm{T})$ and is documented by the $P^{\prime}$ increase. Bottom: In the Bushveld granites, at the scale of the outcrop, we observe no correlation between $P^{\prime}$ and $K$ because $P^{\prime}$ is controlled, at the specimen scale, by the degree of orientation of a small population of MD magnetite particles. Magmatic shear strain at this scale is represented by the average $P^{\prime}$ of the station (small grid). The relatively large variations in $P^{\prime}$ and $K$ are caused by the nugget effect.

stresses of 10-100 MPa (representative of orogenic deformation). In the following we do not discuss brittle shear zones because fractures are likely to host secondary minerals that would not necessarily relate to strain. The physical transformation processes affecting ferromagnesian silicates (paramagnetic minerals) in natural shear zones are mostly plastic deformation mechanisms and recrystallization (e.g., Ferré and Améglio, 2000; Gébelin et al., 2011; Ono et al., 2010). Since these mechanisms modify the lattice-preferred orientation (LPO) of any given mineral in a rock, such changes can affect the relationship between magnetic anisotropy and strain, for example when LPOs switch from girdle to maxima distributions.

Two general categories of deformation mechanisms operate in shear zones, broadly classified as dislocation-dominated or diffusiondominated (e.g., Dunlap et al., 1997). At higher stresses and larger grain sizes, dislocation creep mechanisms are expected to dominate, while at lower stresses and smaller grain sizes, diffusion creep mechanisms become more important (e.g., Housen et al., 1995). As dislocation

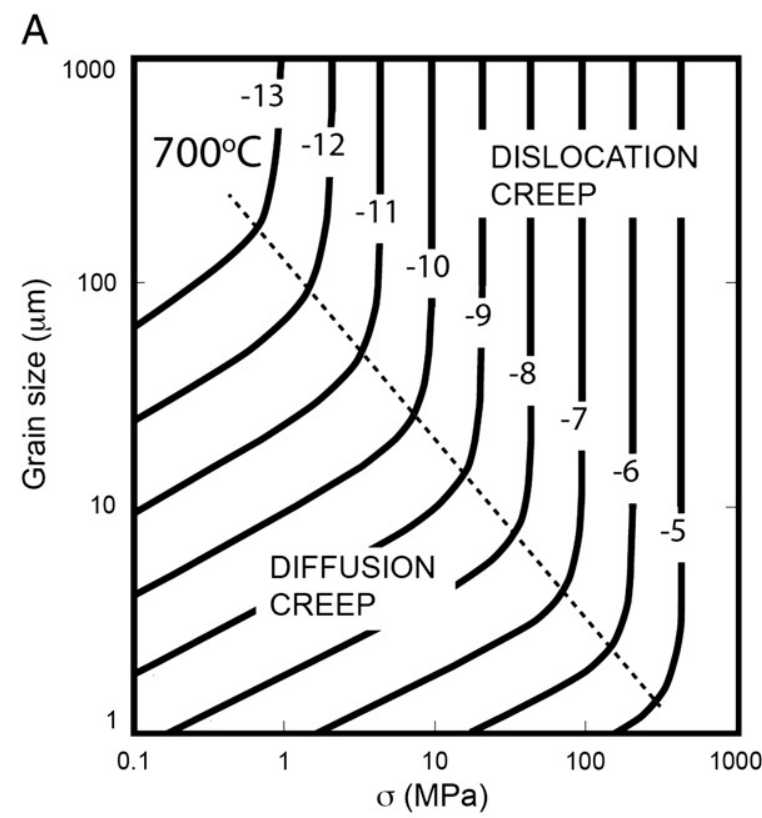

B

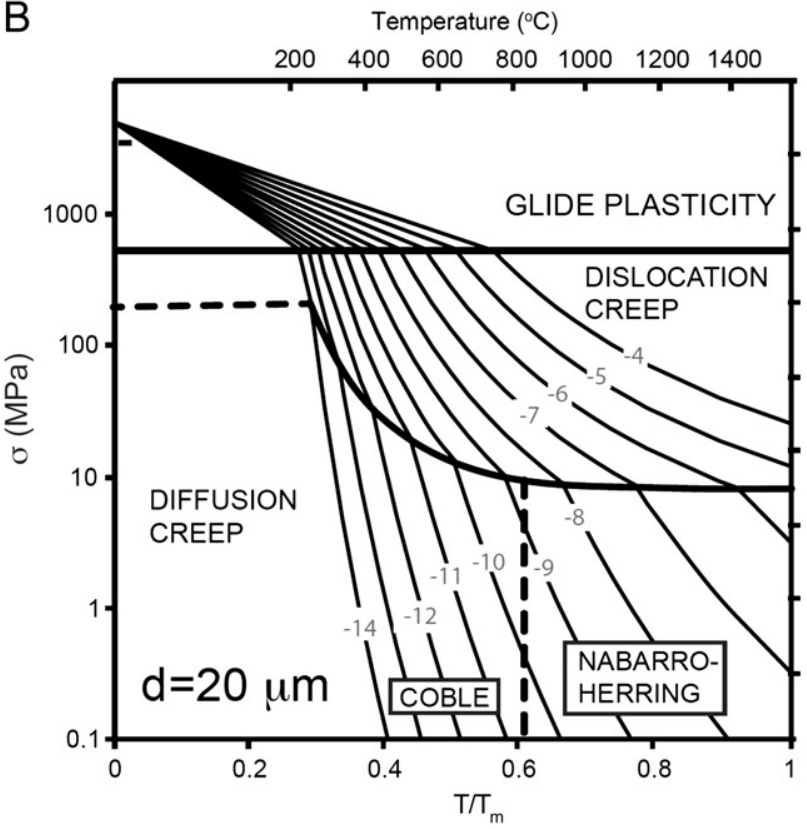

Fig. 5. Deformation mechanism maps for magnetite as a function of A) stress $(\sigma)$ and grain size at a temperature of $700{ }^{\circ} \mathrm{C}$ and $\mathrm{B}$ ) temperature and stress with a constant grain size (d) of $20 \mu \mathrm{m}$, with contour lines label as log strain rate. $\mathrm{T} / \mathrm{T}_{\mathrm{m}}$ refers to temperature/melting temperature. 
creep progresses, rearrangement of dislocations into low-angle grain boundaries is often accompanied by dynamic recrystallization. Dynamic recrystallization consists of two basic processes: subgrain rotation (SGR) and grain boundary migration (GBM) (e.g., Hirth and Tullis, 1992; Poirier and Guillopé, 1979; Poirier and Nicolas, 1975). The interaction between these two processes varies with the temperature of deformation. Microstructural observations in quartz ribbons from a natural ductile shear zone documented three different dynamic recrystallization mechanisms, resulting from the combination of these two processes (Stipp et al., 2002). Transitions from one regime to another occur with increasing temperature, decreasing strain rate or increasing water content and can range between GBM, subgrain rotation, and a mixed regime characterized by activity of both processes. The SGR regime is marked by flattening of grains and numerous subgrains while GBM regime is characterized by either irregular shape of recrystallized grains, lobate sutures or regular shapes and sizes of recrystallized grains with straight or slightly curved joints (Jessell, 1987). When recrystallized grains exhibit such regular shapes and sizes, it indicates a complete recrystallisation and recrystallized grains define an oblique foliation (Dunlap et al., 1997; Means, 1981).

Dynamic recrystallization is the main mechanism responsible for grain size reduction in ductile shear zones and the recrystallized grain size is linked to the paleo-stresses under which steady-state creep occurred (e.g., Bestmann and Prior, 2003). Subgrain rotation and recrystallization is important in the process of initial crystallographic texture development, however at large strains it can also modify the LPO formed at lower strains (Barnhoorn et al., 2004) and therefore can lead to complex paths of LPO evolution. At constant stress conditions, grain size reduction occurring as a result of subgrain boundary rotation and dynamic recrystallization may trigger a change in deformation mechanism from dislocation-dominated creep to creep controlled by diffusion or grain boundary sliding (e.g., Bestmann and Prior, 2003), which may be associated with strain softening and increasing strain rate.

Flow laws for magnetite (Till and Moskowitz, 2013), which is a common source of AMS in shear zone mylonites and ultramylonites, predict that it is capable of deforming by dislocation creep at significant rates at low-to-moderate temperatures. For temperatures as low as $450{ }^{\circ} \mathrm{C}$, deformation mechanism maps (Fig. 5) predict creep rates on the order of $10^{-12} \mathrm{~s}^{-1}$, depending on the grain size. Field studies of shear zones in which plastically deformed magnetite was observed (Agar and Lloyd, 1997; Ferré et al., 2003; Housen et al., 1995; Mims et al., 1990; Werner, 2002) indicate that strain response models other than rigid particle rotation (i.e., models based on internal deformation of magnetite particles) are needed to account for changes in AMS with increasing deformation in magnetite-bearing shear zones.

A

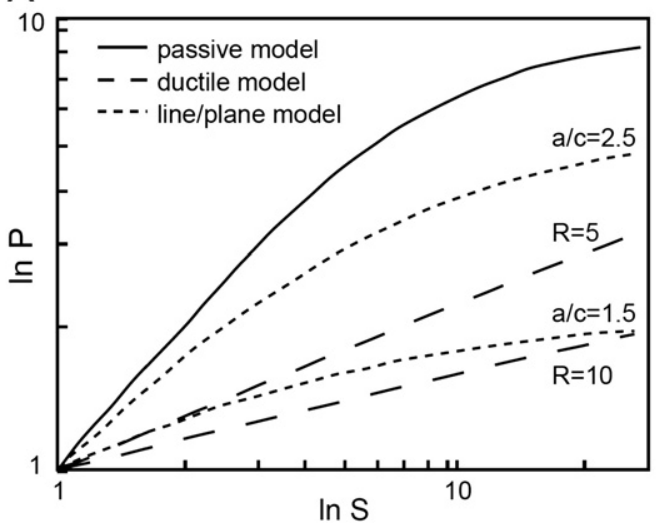

Grain size reduction occurring during mylonitization is expected to produce changes in the grain-scale anisotropy of the AMS-bearing particles. For magnetite, the grain AMS may be significantly reduced by the decrease in intrinsic susceptibility expected for smaller grain sizes, which should result in a lower maximum possible sample AMS. This may explain why Hrouda (1993) concluded that the passive strain response model, which assumes a constant $\kappa_{\mathrm{i}}$ (and therefore constant grain size and composition) during deformation, produces unrealistically large anisotropies and does not represent the natural response of magnetite to deformation in nature. The Brevard shear zone in North Carolina (Goldstein and Brown, 1988) and the Santa Catalina mylonite in Arizona (Ruf et al., 1988) show broad decrease of magnetic anisotropy towards the center of the shear zone. Our observations indicate that the protolith is lithologically far too heterogeneous to draw general conclusions from this example.

Changes in composition as well as grain size of AMS-bearing minerals during deformation can also be expected to alter the grain-scale anisotropy of individual minerals, and therefore the maximum "end member" magnetic fabric intensity may change continuously during deformation. Thus, the modeled paths for AMS development shown in Fig. 6 should only be expected to hold in the early stages of shear zone development before mylonitization, where compositional changes and syn-deformational reactions are limited. Strain partitioning, which is a common occurrence in shear zones, also means that the magnetic fabric intensity can be biased by various mineral subfabrics rather than reflecting the whole-rock strain or the overall deformation petrofabric.

Cases of boudinaged magnetite have been observed (Sidman et al., 2005) and may explain the correlation between $P^{\prime}$ and $K$, at least in some cases. In such cases, magnetite develops a distribution anisotropy such as that described by Hargraves et al. (1991).

Finally, LPO measurements using the electron backscattered diffraction technique show that titanohematite deformed mainly by dislocation creep in a high-temperature mylonitic granulite (Bascou et al., 2002). This is in contradiction with other deformation maps (Tarling and Hrouda, 1993) which predict coble creep mechanism. A possible explanation is that the deviatoric stress was higher in this shear zone.

\section{Experimental studies of AMS in shear zones}

Experimental deformation of various rocks and rock-analogs has been used to study a variety of AMS-bearing minerals, including magnetite (Arbaret et al., 1997; Borradaile and Alford, 1988; Borradaile and Puumala, 1989; Jackson et al., 1993; Till et al., 2010, 2012), hematite (Cogne and Canot-Laurent, 1992), and phyllosilicates (Bruijn et al., 2013; Kapička et al., 2006), and diamagnetic AMS fabrics in calcite (Owens and Rutter, 1978). These experiments yielded a number of

B

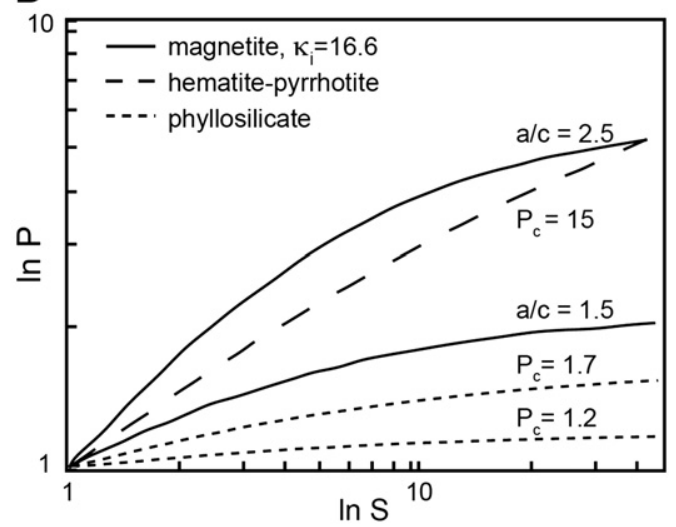

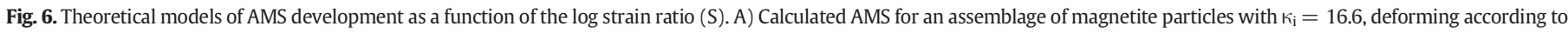

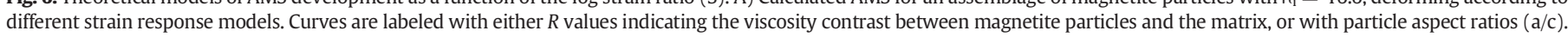
B) Comparison of calculated AMS for different types of minerals deforming according to the line/plane model with varying grain anisotropies ( $\mathrm{P}_{\mathrm{c}}$ ) or aspect ratios. 
insights into the development of AMS in shear zones. Simple shear deformation was noted to be extremely efficient in producing magnetic anisotropy compared with axial shortening (Borradaile and Alford, 1988), particularly where AMS development was due to particle rotation and alignment. A number of experimenters report irreversible changes in rock magnetic properties of magnetite subjected to hydrostatic or non-hydrostatic stress (Borradaile and Jackson, 1993; Gilder and Le Goff, 2008; Jackson et al., 1993; Kapička et al., 1996). Such stress effects will also influence the magnetic behavior of magnetite during shear zone development and should be taken into account when interpreting AMS data.

Various experimental studies have also noted the importance of initial fabric, or magnetic anisotropy of the protolith, for shear deformation fabrics measured by AMS (Borradaile, 1988; Borradaile and Alford, 1988; Borradaile and Puumala, 1989; Till et al., 2010). These experiments emphasized that knowledge of the pre-shearing fabric is critical for making interpretations of relative strain from AMS data, particularly at low-to-moderate strains. While some studies confirmed the predicted degree of AMS development calculated by theoretical strain response models (e.g., Till et al., 2010), other studies found more complicated relationships that cannot be explained by the simple models (Jackson et al., 1993; Kapička et al., 2006). Variations in degree of clast-matrix coupling most likely play a significant role in these complications (Johnson et al., 2009).

\section{Composite AMS fabrics, shear sense indicators and deformation regime}

Composite AMS fabrics occur when the shape and orientation of the AMS ellipsoid results from two or more components having different mineral-preferred orientations (Borradaile and Tarling, 1981; Housen et al., 1993). For example, in sheared porphyroclastic rocks displaying C-S structures (Fig. 7), the magnetic foliation, defined by the $K_{1}-K_{2}$ plane (and perpendicular to $K_{3}$ ), is parallel to the bisecting plane of the C- and S-planes (Aranguren et al., 1996; Sidman et al., 2005; Tomezzoli et al., 2003; Zhou et al., 2002). The magnetic foliation spins towards the shear plane as deformation increases towards the shear zone. Surprisingly, the AMS lineation $K_{1}$ is close to the mineral lineation and not to the intersection (zone axis) of the C- and S-planes as might have been expected. This might be caused by the AMS contribution of small secondary oxide grains that formed by destabilization of biotite during mylonitization.

In simple shear, the AMS ellipsoid obliquity on the shear plane can be used as a shear-sense indicator (Fig. 8) for small strains $(\gamma<3$; Benn, 1994), and even at higher shear strains $(\gamma>6)$ in the case of interacting particles (Arbaret et al., 1997). At high shear strains, caution should be exercised because the angle between the shear plane and the magnetic foliation becomes very small, and also because the shear plane attitude may vary locally (Zhou et al., 2002). The sense of shear can also be obtained by determining the magnetic fabrics of two subpopulations of AMS markers having distinct aspect ratios (Ferré et al., 2004).

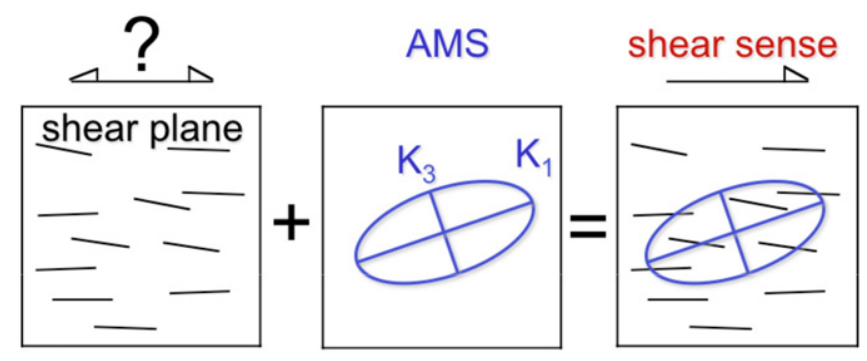

Fig. 8. AMS ellipsoid obliquity on the shear plane can be used as a shear-sense indicator.

The deformation regime (i.e., simple shear vs. pure shear) in shear zones has long been a subject of discussion (Coward, 1976). In pure shear, correlations between AMS and strain are best between 25 and $75 \%$ strain (Borradaile, 1991). This criterion may be used in some cases to evaluate the deformation regime. One of the fundamental drawbacks of the AMS method is the potential for saturation of AMS, which develops when magnetic carriers come into near perfect alignment. Such alignments are most frequently encountered with paramagnetic minerals (Borradaile, 1991). In contrast, there is no AMS saturation up to shear strains of $\gamma=13$ in magnetite-bearing ultramylonites (Housen et al., 1995). In simple shear, the shear strain $\gamma$ can be calculated from Ramsay and Huber's (1987)'s formula: $\gamma=2 / \tan 2 \varphi^{\prime}$ with $\varphi^{\prime}$ being the angle between $K_{1}$ (or $K_{\max }$ in 2-D) and the shear plane (Fig. 9). Djouadi et al. (1997) used this approach to estimate shear strain during emplacement of two plutons. The deformation regime also controls the geometric relationship between the transport direction and the mineral stretching lineation (Tikoff and Greene, 1997). Examples of transpressive shear zones with vertical lineations have been reported in the Sierra Nevada Batholith (Tikoff and Greene, 1997) and in the Superior Province (Czeck and Hudleston, 2003). This type of complication in shear zone kinematics can be resolved using the AMS technique because it provides a quick method to determine plastic flow direction.

\section{Conclusions}

Ductile shear zones constitute domains where deformation is heterogeneous and commonly partitioned as a result of variations in rock strength at the scale of the outcrop. The anisotropy of magnetic susceptibility (AMS) provides unparalleled opportunities to track variations in strain magnitude and in the orientation of the principal strain directions. The positive, albeit non-linear, correlation observed in many studies between the degree of magnetic anisotropy $\left(P^{\prime}\right)$ and strain $(\varepsilon)$, justifies the use of AMS as a proxy for strain. However, detailed structural investigations of ductile shear zones with magnetic fabrics require a thorough analysis of the nature of magnetic markers and the deformation mechanisms responsible for their orientation. In cases where the shear zone composition remains relatively constant, the AMS could provide valuable information regarding longitudinal and lateral variations in the deformation mechanisms. In turn, this information could be

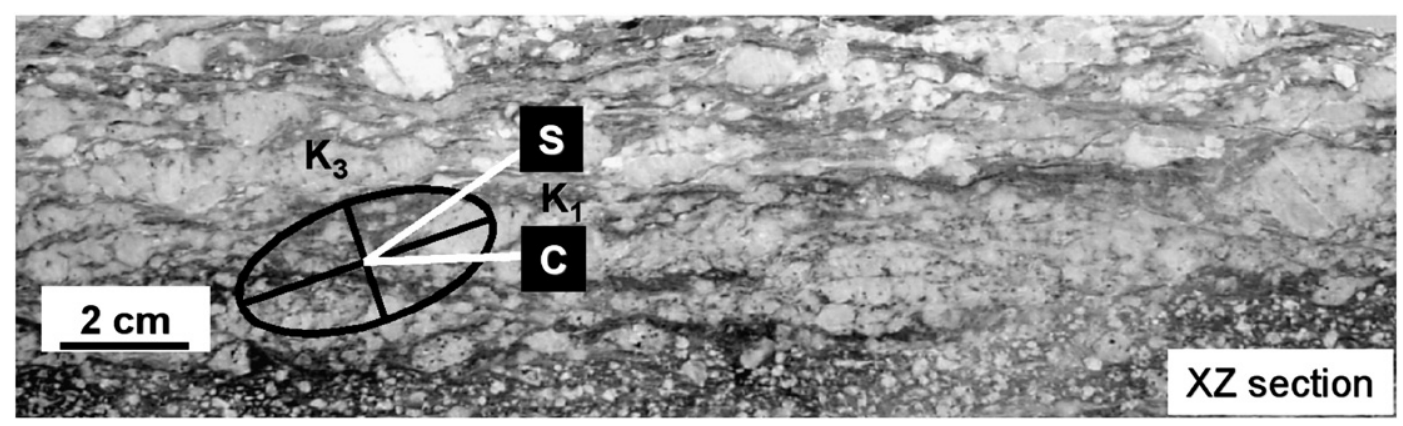

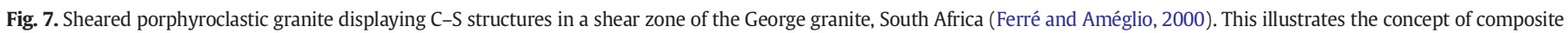
AMS fabrics. 


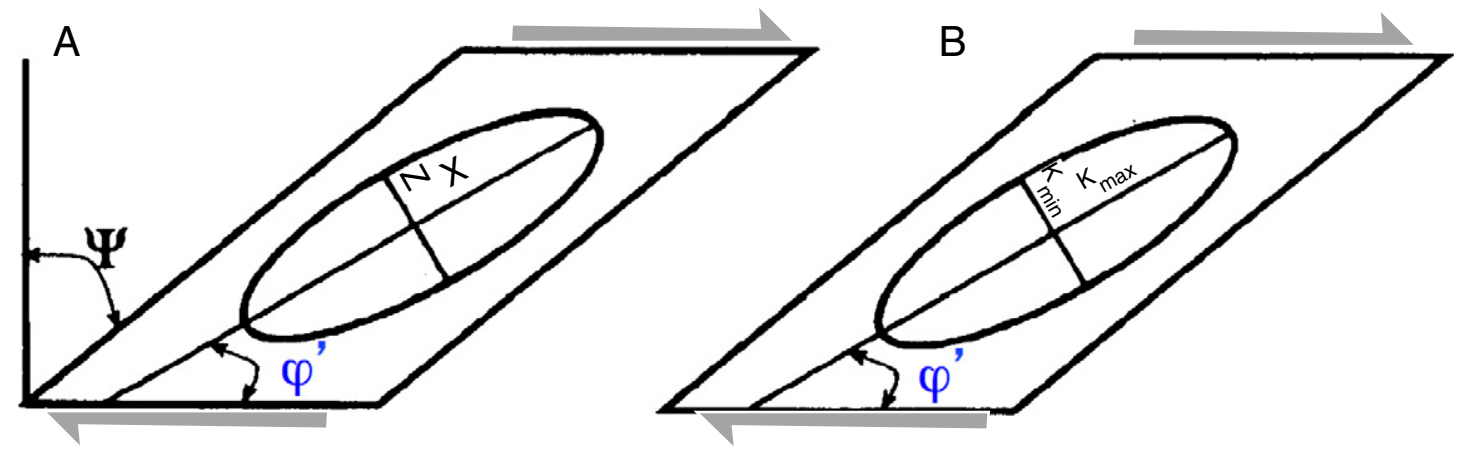

Fig. 9. Angular relationship between finite strain directions and AMS principal directions.

used as a preliminary guide for strain rate studies. In addition to its significant potential as a structural tool in shear zones, the AMS also holds kinematic information arising from the obliquity of the magnetic fabric with respect to the shear plane. Finally, while the relationship between $P^{\prime}$ and $\varepsilon$ might be complicated due to lithological variations within the shear zone, the angular information contained in $\varphi^{\prime}$ (the angle between $K_{1}$ and the shear plane) appears to be a more robust estimate of shear strain $\gamma$ than the degree of anisotropy $P^{\prime}$.

\section{Acknowledgments}

The authors are particularly indebted to the co-guest editor, France Lagroix, for her professional handling of this manuscript. The authors also acknowledge the review of Paul Kelso who contributed greatly to strengthening this work.

\section{References}

Agar, S.M., Lloyd, G.E., 1997. Deformation of Fe-Ti oxides in gabbroic shear zones from the MARK area. In: Karson, J.A., Cannat, M., Miller, D.J., Agar, S.M., Barling, J., Casey, J.F., Ceuleneer, G., Dilek, Y., Fletcher, J.M., Fujibayashi, N., Gaggero, L., Gee, J.S., Hurst, S.D., Kelley, D.S., et al. (Eds.), Proceedings of the Ocean Drilling Program. Scientific Results, vol. 153, pp. 123-141.

Anchuela, P.Ó., Ramajo Cordero, J., Gil Imaz, A., Meléndez Hevia, G., 2012. Analysis of anisotropy of magnetic susceptibility in iron-oolitic beds: a potential tool for paleocurrent identification. Int. J. Earth Sci. 102, 1131-1149. http://dx.doi.org/10. 1007/s00531-012-0848-2.

Aranguren, A., Cuevas, J., Tubía, J.M., 1996. Composite magnetic fabrics from SC mylonites. J. Struct. Geol. 18, 863-869.

Arbaret, L., Diot, H., Bouchez, J.L., 1996. Shape fabrics of particles in low concentration suspensions: 2D analogue experiments and application to tiling in magma. J. Struct. Geol. 18, 941-950.

Arbaret, L., Diot, H., Bouchez, J.L., Lespinasse, P., de Saint-Blanquat, M., 1997. Analogue 3D simple-shear experiments of magmatic biotite subfabrics. In: Bouchez, J.L., Hutton, D.H.W., Stephens, W.E. (Eds.), Granite: From Segregation of Melt to Emplacement Fabrics, vol. 8. Kluwer Publishing Co., Dordrecht, pp. 129-144.

Arbaret, L., Fernandez, A., Jezek, J., Ildefonse, B., Launeau, P., Diot, H., 2000. Analogue and numerical modelling of shape fabrics; application to strain and flow determination in magmas. In: Barbarin, B., Stephens, W.E., Bonin, B., Bouchez, J.L., Clarke, D.B., Cuney, M., Martin, H. (Eds.), Transactions of the Royal Society of Edinburgh: Earth Sciences, vol. 91, n. 1-2, pp. 97-109.

Aubourg, C., Hebert, R., Jolivet, L., Cartayrade, G., 2000. The magnetic fabric of metasediments in a detachment shear zone: the example of Tinos Island (Greece). Tectonophysics 321, 219-236.

Aydin, A., Ferré, E.C., Aslan, Z., 2007. The magnetic susceptibility of granitic rocks as a proxy for geochemical composition: example from the Saruhan granitoids, NE Turkey. Tectonophysics 441, 85-95. http://dx.doi.org/10.1016/j.tecto.2007.04.009.

Barnhoorn, A., Bystricky, M., Burlini, L., Kunze, K., 2004. The role of recrystallisation on the deformation behaviour of calcite rocks: large strain torsion experiments on Carrara marble. J. Struct. Geol. 26 (5), 885-903.

Bascou, J., Raposo, M.I.B., Vauchez, A., Egydio-Silva, M., 2002. Titanohematite latticepreferred orientation and magnetic anisotropy in high-temperature mylonites. Earth Planet. Sci. Lett. 198, 77-92.

Belley, F., Ferré, E.C., Martl̀n-Hernandez, F.t., Jackson, M.J., Dyar, M.D., Catlos, E.J., 2009. The magnetic properties of natural and synthetic (Fex, Mg1-x)2 SiO4 olivines. Earth and Planetary Science Letters 284 (3-4), 516-526.

Benn, K., 1994. Overprinting of magnetic fabrics in granites by small strains: numerical modelling. Tectonophysics 233, 153-162.

Bestmann, M., Prior, D.J., 2003. Intragranular dynamic recrystallization in naturally deformed calcite marble: diffusion accommodated grain boundary sliding as a result of subgrain rotation recrystallization. J. Struct. Geol. 25 (10), 1597-1613.
Borradaile, G.J., 1987. Anisotropy of magnetic susceptibility: rock composition versus strain. Tectonophysics $138,327-329$.

Borradaile, G.J., 1988. Magnetic susceptibility, petrofabrics and strain. Tectonophysics 156 1-20.

Borradaile, G.J., 1991. Correlation of strain with anisotropy of magnetic susceptibility (AMS). Pure Appl. Geophys. 135, 15-29.

Borradaile, G.J., 1993. The rotation of magnetic grains. Tectonophysics 221, 381-384.

Borradaile, G.J., 2001. Magnetic fabrics and petrofabrics: their orientation distributions and anisotropies. J. Struct. Geol. 23, 1581-1596.

Borradaile, G., Alford, C., 1987. Relationship between magnetic susceptibility and strain in laboratory and experiments. Tectonophysics 133, 121-135.

Borradaile, G.J., Alford, C., 1988. Experimental shear zones and magnetic fabrics. J. Struct. Geol. 10, 895-904.

Borradaile, G.J., Henry, B., 1997. Tectonic applications of magnetic susceptibility and its anisotropy. Earth Sci. Rev. 42, 49-93.

Borradaile, G.J., Jackson, M., 1993. Changes in magnetic remanence during simulated deep sedimentary burial. Phys. Earth Planet. Inter. 77, 315-327.

Borradaile, G.J., Jackson, M., 2004. Anisotropy of magnetic susceptibility (AMS); magnetic petrofabrics of deformed rocks. In: Martin-Hernandez, F., Lueneburg, C.M., Aubourg C., Jackson, M. (Eds.), Magnetic Fabric; Methods and Applications. Geological Society Special Publications, London, pp. 299-360.

Borradaile, G.J., Jackson, M., 2010. Journal of structural geology. J. Struct. Geol. 32, 1519-1551. http://dx.doi.org/10.1016/j.jsg.2009.09.006.

Borradaile, G., Mothersill, J., 1989. Tectonic strain and paleomagnetism: experimental investigation. Phys. Earth Planet. Inter. 56, 254-265.

Borradaile, G.J., Puumala, M.A., 1989. Synthetic magnetic fabrics in a plasticene medium. Tectonophysics 164, 73-78.

Borradaile, G.J., Tarling, D.H., 1981. The influence of deformation mechanisms on magnetic fabrics in weakly deformed rocks. Tectonophysics 77, 151-168.

Borradaile, G.J., Werner, T., 1994. Magnetic anisotropy of some phyllosilicates. Tectonophysics 235, 223-248.

Bouchez, J.L., 1997. Granite is never isotropic: an introduction to AMS studies of granitic rocks. In: Bouchez, J.L., Hutton, D.H.W., Stephens, W.E. (Eds.), Granite: From Segregation of Melt to Emplacement Fabrics. Petrology and Structural Geology, 8. Kluwer Publishing Co., Dordrecht, pp. 95-112.

Boutonnet, E., Leloup, P.H., Sassier, C., Gardien, V., Ricard, Y., 2013. Ductile strain rate measurements document long-term strain localization in the continental crust. Geology 41, 819-822. http://dx.doi.org/10.1130/G33723.1.

Bruijn, R.H.C., Almqvist, B.S.G., Hirt, A.M., Benson, P.M., 2013. Decoupling of paramagnetic and ferrimagnetic AMS development during the experimental chemical compaction of illite shale powder. Geophys. J. Int. 192, 975-985. http://dx.doi.org/10.1093/gji/ ggs086.

Burmeister, K.C., Harrison, M.J., Marshak, S., Ferré, E.C., Bannister, R.A., Kodama, K.P., 2009 Comparison of Fry strain ellipse and AMS ellipsoid trends to tectonic fabric trends in very low-strain sandstone of the Appalachian fold-thrust belt. J. Struct. Geol. 31, 1028-1038. http://dx.doi.org/10.1016/j.jsg.2009.03.010.

Cañón-Tapia, E., 2004. Anisotropy of magnetic susceptibility of lava flows and dykes: a historical account. In: Martín-Hernández, F., Lüneburg, C.M., Aubourg, C., Jackson, M. (Eds.), Magnetic Fabric: Methods and Applications. Geological Society, London, pp. 205-225.

Cifelli, F., Mattei, M., Chadima, M., Lenser, S., Hirt, A.M., 2009. The magnetic fabric in "undeformed clays": AMS and neutron texture analyses from the Rif Chain (Morocco). Tectonophysics 466, 79-88. http://dx.doi.org/10.1016/j.tecto.2008.08.008.

Cogne, J.P., Canot-Laurent, S., 1992. Simple shear experiments on magnetized waxhematite samples. Earth Planet. Sci. Lett. 112, 147-159.

Cogne, J.P., Perroud, H., 1988. Anisotropy of magnetic susceptibility as a strain gauge in the Flamanville Granite, NW France. In: Ellwood Brooks, B., Hrouda, F., Wagner, J.-J. (Eds.), Physics of the Earth and Planetary Interiors, vol. 51, pp. 264-270.

Collinson, D.W., Creer, K.M., Runcorn, S.K., 1967. Methods in Palaeomagnetism. Elsevier, Amsterdam (609 pp.).

Coward, M.P., 1976. Strain within ductile shear zones. Tectonophysics 34, 181-197.

Czeck, D.M., Hudleston, Peter J., 2003. Testing models for obliquely plunging lineations in transpression: a natural example and theoretical discussion. J. Struct. Geol. 25, 959-982

de Wall, H., Bestmann, M., Ullemeyer, K., 2000. Anisotropy of diamagnetic susceptibility in Thassos marble: a comparison between measured and modeled data. J. Struct. Geol. 22, 1761-1771. 
Djouadi, M.T., Gleizes, G., Ferré, E., Bouchez, J.L., Caby, R., Lesquer, A., 1997. Oblique magmatic structures of two epizonal plutons, Hoggar, Algeria: late-orogenic emplacement in a transcurrent orogen. Tectonophysics 279, 351-374.

Dunlap, W.J., Hirth, G., Teyssier, C., 1997. Thermomechanical evolution of a ductile duplex. Tectonics 16, 983-1000.

Dunlop, D.J., 1984. A method of determining demagnetizing factor from multidomain hysteresis. J. Geophys. Res. 89, 553-558.

Dunlop, D.J., Ozdemir, O., Rancourt, D.G., 2006. Magnetism of biotite crystals. Earth Planet Sci. Lett. 243, 805-819. http://dx.doi.org/10.1016/j.epsl.2006.01.048.

Ellwood Brooks, B., Balsam, W.L., Burkhart, B., Long, G.J., Buhl, M.L., 1986. Anomalous magnetic properties in rocks containing the mineral siderite; paleomagnetic implications. J. Geophys. Res. 91, 12779-12790.

Evans, M.A., Lewchuk, M.T., Elmore, R.D., 2003. Strain partitioning of deformation mechanisms in limestones: examining the relationship of strain and anisotropy of magnetic susceptibility (AMS). J. Struct. Geol. 25, 1525-1549.

Ferré, E.C., Améglio, L., 2000. Preserved magnetic fabrics vs. annealed microstructures in the syntectonic recrystallised George granite, South Africa. J. Struct. Geol. 22, 1199-1219.

Ferré, E.C., Gleizes, G., Djouadi, M.T., Bouchez, J.L., 1997. Drainage and emplacement of magmas along an inclined transcurrent shear zone: petrophysical evidence from a granite-charnockite pluton (Rahama, Nigeria). In: Bouchez, J.L., Stephens, W.E.S., Hutton, D.H.W. (Eds.), Granites: From Magma Segregation to Emplacement Fabrics. Kluwer Academic Publishers, pp. 253-273.

Ferré, E.C., Wilson, J., Gleizes, G., 1999. Magnetic susceptibility and AMS of the Bushveld alkaline granites, South Africa. Tectonophysics 307, 113-133.

Ferré, E.C., Teyssier, C., Jackson, M.J., Thill, J.V., Rainey, E.S.G., 2003. Magnetic susceptibility anisotropy: a new petrofabric tool in migmatites. J. Geophys. Res. 108. http://dx.doi. org/10.1029/2002JB001790.

Ferré, E.C., Martín-Hernández, F., Teyssier, C., Jackson, M., 2004. Paramagnetic and ferromagnetic anisotropy of magnetic susceptibility in migmatites: measurements in high and low fields and kinematic implications. Geophys. J. Int. 157, 1119-1129.

Ferré, E.C., Michelsen, K.J., Ernst, W.G., Boyd, J.D., Canon-Tapia, E., 2012. Vertical zonation of the Barcroft granodiorite, White Mountains, California: implications for magmatic processes. Am. Mineral. 97, 1049-1059. http://dx.doi.org/10.2138/am.2012.4013.

Fleming, E.J., et al., 2013. Magnetic fabrics in the basal ice of a surge-type glacier. J. Geophys. Res. Earth Surf. 118 (4), 2263-2278.

Foster, D.A., Schafer, C., Fanning, C.M., Hyndman, D.W., 2001. Relationships between crustal partial melting, plutonism, orogeny, and exhumation: Idaho-Bitterroot batholith. Tectonophysics 342, 313-350.

Gébelin, A., Martelet, Chen, Y., Brunel, M., Faure, M., 2006. Structure of late Variscan Millevaches leucogranite massif in the French Massif Central: AMS and gravity modeling results. J. Struct. Geol. 28, 148-169.

Gébelin, A., Mulch, A., Teyssier, C., Heizler, M., Venneman, T., Seaton, N.C.A., 2011. OligoMiocene extensional tectonics and fluid flow across the Northern Snake Range detachment system, Nevada. Tectonics 30, 1-18. http://dx.doi.org/10.1029/ 2010 TC002797 (TC5010).

Gentoso, M.J., Evenson, E.B., Kodama, K.P., Iverson, N.R., Alley, R.B., Berti, C., Kozlowski, A 2012. Exploring till bed kinematics using AMS magnetic fabrics and pebble fabrics: the Weedsport drumlin field, New York State, USA. Boreas 41, 31-41. http://dx.doi $\operatorname{org} / 10.1111 / \mathrm{j} .1502-3885.2011 .00221 . x$.

Gilder, S.A., Le Goff, M., 2008. Systematic pressure enhancement of titanomagnetite mag netization. Geophys. Res. Lett. 35, L10302. http://dx.doi.org/10.1029/2008GL033325.

Giordano, D., Russell, J.K., Dingwell, D.B., 2008. Viscosity of magmatic liquids: a model. Earth Planet. Sci. Lett. 271, 123-134.

Gleizes, G., 1992. Structure des granites hercyniens des Pyrénées de Mont-Louis-Andorre à la Maladeta. Unpublished Doctorate Thesis, Toulouse, France.

Gleizes, G., Nédelec, A., Bouchez, J.L., Autran, A., Rochette, P., 1993. Magnetic susceptibility of the Mont-Louis Andorra ilmenite-type granite (Pyrenees); a new tool for the petrographic characterization and regional mapping of zoned granite plutons. J. Geophys. Res. 98, 4317-4331.

Goldstein, A.G., 1980. Magnetic susceptibility anisotropy of mylonites from the Lake Char mylonite zone, southeastern New England. Tectonophysics 66, 197-211.

Goldstein, A.G., Brown, L.L., 1988. Magnetic susceptibility anisotropy of mylonites from the Brevard zone, North Carolina, USA. Phys. Earth Planet. Inter. 51, 290-300.

Goodwin, L.B., Tikoff, B., 2002. Competency contrast, kinematics, and the development of foliations and lineations in the crust. J. Struct. Geol. 24, 1065-1085.

Graham, J.W., 1954. Magnetic susceptibility anisotropy, an unexploited petrofabric element. Geol. Soc. Am. Bull. 65, 1257-1258.

Graham, J.W., 1966. Significance of magnetic anisotropy in Appalachian sedimentary rocks. The Earth Beneath the Continents-A Volume of Geophysical Studies in Honor of Merle A. TuveAmerican Geophysical Union, Washington, DC, United States pp. 627-648.

Granar, L., 1958. Magnetic measurements on Swedish varved sediments. Ark. Geofys. 3, 1-40.

Grégoire, V., Darrozes, J., Gaillot, P., Nédélec, A., Launeau, P., 1998. Magnetite grain shape fabric and distribution anisotropy vs. rock magnetic fabric: a three-dimensional case study. J. Struct. Geol. 20, 937-944.

Hargraves, R.B., Johnson, D., Chan, C.Y., 1991. Distribution anisotropy; the cause of AMS in igneous rocks? Geophys. Res. Lett. 18, 2193-2196.

Henry, B., Daly, L., 1983. From qualitative to quantitative magnetic anisotropy analysis: the prospect of finite strain calibration. Tectonophysics 98, 327-336.

Hirt, A.M., Almqvist, B.G., 2013. Unraveling magnetic fabrics. Int. J. Earth Sci. 101 (3), 613-624.

Hirt, A.M., Gehring, A.U., 1991. Thermal alteration of the magnetic mineralogy in ferruginous rocks. J. Geophys. Res. 96, 9947-9953.

Hirt, A.M., Lowrie, W., Clendenen, W.S., Kligfield, R., 1993. Correlation of strain and the anisotropy of magnetic susceptibility in the Onaping Formation: evidence for near-circular origin of the Sudbury Basin. Tectonophysics 225, 231-254.
Hirth, G., Tullis, J., 1992. Dislocation creep regimes in quartz aggregates. J. Struct. Geol. 14, 145-159.

Hobbs, B., Mühlhaus, H.-B., Ord, A., 1990. Instability, softening and localization of deformation. Geol. Soc. Lond. Spec. Publ. 54 (1), 143-165.

Hodych, J., 1986. Determination of self-demagnetizing factor $N$ for multidomain magnetite grains in rock. Phys. Earth Planet. Inter. 41 (4), 283-291.

Housen, B.A., van der Pluijm, B.A., 1990. Chlorite control of correlations between strain and anisotropy of magnetic susceptibility. Phys. Earth Planet. Inter. 61, 315-323.

Housen, B.A., Richter, C., van der Pluijm, B.A., 1993. Composite magnetic anisotropy fabrics: experiments, numerical models and implications for the quantification of rock fabrics. Tectonophysics $220,1-12$

Housen, B.A., van der Pluijm, B.A., Essene, E.J., 1995. Plastic behavior of magnetite and high strains obtained from magnetic fabrics in the Parry Sound shear zone, Ontario Grenville Province. J. Struct. Geol. 17, 265-278.

Hrouda, F., 1982. Magnetic anisotropy of rocks and its application in geology and geophysics. Geophys. Surv. 5, 37-82.

Hrouda, F., 1987. Mathematical model relationship between the paramagnetic anisotropy and strain in slates. Tectonophysics $142,323-327$.

Hrouda, F., 1993. Theoretical models of magnetic anisotropy to strain relationship revisited. Phys. Earth Planet. Inter. 77, 237-249.

Hrouda, F., Janak, F., 1976. The changes in shape of the magnetic susceptibility ellipsoid during progressive metamorphism and deformation. Tectonophysics $34,135-148$.

Hrouda, F., Lanza, R., 1989. Magnetic fabric in the Biella and Traversella stocks (Periadriatic Line): implications for the mode of emplacement. Phys. Earth Planet. Inter. 56, 337-348.

Hrouda, F., Henry, B., Borradaile, G., 2000. Limitations of tensor subtraction in isolating diamagnetic fabrics by magnetic anisotropy. Tectonophysics 322, 303-310.

Hrouda, F., Chlupacova, M., Schulmann, K., Šmíd, J., Závada, P., 2005. On the effect of lava viscosity on the magnetic fabric intensity in alkaline volcanic rocks. Stud. Geophys. Geod. 49, 191-212.

Hunt, C.P., Moskowitz, B.M., Banerjee, S.K., 1995. Magnetic properties of rocks and minerals. In: Ahrens, T.J. (Ed.), A Handbook of Physical Constants, vol. 3. American Geophysical Union, Washington, DC, pp. 189-204.

Ihmlé, P.F., Hirt, A.M., Lowrie, W., Dietrich, D., 1989. Inverse magnetic fabric in deformed limestones of the Morcles nappe, Switzerland. Geophys. Res. Lett. $16,1383-1386$.

Jackson, M., Borradaile, G., Hudleston, P., Banerjee, S., 1993. Experimental deformation of synthetic magnetite-bearing calcite sandstones: effects on remanence, bulk magnetic properties, and magnetic anisotropy. J. Geophys. Res. 98 (B1), 383-401.

Jackson, M., Moskowitz, B., Rosenbaum, J., Kissel, C., 1998. Field-dependence of AC susceptibility in titanomagnetites. Earth Planet. Sci. Lett. 157 (3), 129-139.

Jelinek, V., 1981. Characterization of the magnetic fabric of rocks. Tectonophysics 79, T63-T67.

Jessell, M.W., 1987. Grain-boundary migration microstructures in a naturally deformed quartzite. J. Struct. Geol. 9 (8), 1007-1014.

Johnson, S.E., Lenferink, H.J., Price, N.A., Marsh, J.H., Koons, P.O., West Jr., D.P., Beane, R., 2009. Clast-based kinematic vorticity gauges: the effects of slip at matrix/clast interfaces. J. Struct. Geol. 31 (11), 1322-1339.

Kankeu, B., Greiling R.O., Nzenti, J.P., Bassahak, J., Hell, J.V., 2012. Strain partitioning along the Neoproterozoic Central Africa Shear Zone system: structures and magnetic fabrics (AMS) from the Meiganga area, Cameroon. N. Jb. Geol. Paläont. (Abh.) 265, 27-47. http://dx.doi.org/10.1127/0077-7749/2012/0244.

Kapička, A., Kobr, M., Pichl, R., 1996. Changes of parameters of magnetic anisotropy of foliated rocks under pressure. Stud. Geophys. Geod. 40 (4), 421-429.

Kapička, A., Hrouda, F., Petrovský, E., Poláček, J., 2006. Effect of plastic deformation in laboratory conditions on magnetic anisotropy of sedimentary rocks. High Press. Res. 26 (4), 549-553.

Kligfield, R., Lowrie, W., Dalziel, I.W.D., 1977. Magnetic susceptibility anisotropy as a strain indicator in the Sudbury Basin, Ontario. Tectonophysics 40, 287-308.

Kligfield, R., Owens, W.H., Lowrie, W., 1981. Magnetic susceptibility anisotropy, strain, and progressive deformation in Permian sediments from the Maritime Alps (France). Earth Planet. Sci. Lett. 55, 181-189.

Kontny, A., Engelmann, R., Grimmer, J.C., Greiling, R.O., Hirt, A., 2012. Magnetic fabric development in a highly anisotropic magnetite-bearing ductile shear zone (Seve Nappe Complex, Scandinavian Caledonides). Int. J. Earth Sci. 101 (3), 671-692.

Kruckenberg, S.C., Vanderhaeghe, O., Ferré, E.C., Teyssier, C., Whitney, D.L., 2011. Flow of partially molten crust and the internal dynamics of a migmatite dome, Naxos, Greece. Tectonics 30. http://dx.doi.org/10.1029/2010TC002751.

Lagroix, F., Borradaile, G.J., 2000. Magnetic fabric interpretation complicated by inclusions in mafic silicates. Tectonophysics 325, 207-225.

Law, R.D., Knipe, R.J., Dayan, H., 1984. Strain path partitioning within thrust sheets: microstructural and petrofabric evidence from the Moine Thrust zone at Loch Eriboll, northwest Scotland. J. Struct. Geol. 6, 477-497.

Leblanc, D., Gleizes, G., Roux, L., L., B.J., 1996. Variscan dextral transpression in the French Pyrenees: new data from the Pic des Trois-Seigneurs granodiorite and its country rock. Tectonophysics $261,331-345$

Leloup, P.H., Lacassin, R., Tapponnier, P., Schärer, U., Zhong, D., Liu, X., Zhang, L., Ji, S., Trinh, P.T., 1995. The Ailao Shan-Red River shear zone (Yunnan, China), Tertiary transform boundary of Indochina. Tectonophysics 251 (1), 3-84.

Liu, Q., Yu, Y., Muxworthy, A.R., Roberts, A.P., 2008. Effects of internal stress on remanence intensity jumps across the Verwey transition for multi-domain magnetite. Phys. Earth Planet. Inter. 169 (1-4), 100-107.

Loock, S., Diot, H., Wyk, Van, de Vries, B., Launeau, P., Merle, O., Vadeboin, F., Petronis, M.S., 2008. Journal of volcanology and geothermal research. J. Volcanol. Geotherm. Res. 177, 1092-1104. http://dx.doi.org/10.1016/j.jvolgeores.2008.08.017. 
Lüneburg, C.M., Lampert, S.A., Lebit, H.D., Hirt, A.M., Casey, M., Lowrie, W., 1999. Magnetic anisotropy, rock fabrics and finite strain in deformed sediments of SW Sardinia (Italy). Tectonophysics 307, 51-74.

Mamtani, M.A., Piazolo, S., Greiling, R.O., Kontny, A., Hrouda, F., 2011. Process of magnetite fabric development during granite deformation. Earth Planet. Sci. Lett. 308 (1-2), 77-89.

Martin-Hernandez, F., Ferré, E.C., 2007. Separation of paramagnetic and ferrimagnetic anisotropies: a review. J. Geophys. Res. 112, B03105. http://dx.doi.org/10.1029/ 2006JB004340.

Martín-Hernández, F., Hirt, A.M., 2003. The anisotropy of magnetic susceptibility in biotite, muscovite and chlorite single crystals. Tectonophysics 367, 13-28. http://dx.doi.org/10.1016/S0040-1951(03)00127-6.

Means, W.D., 1981. The concept of steady-state foliation. Tectonophysics 78 (1-4), 179-199.

Mertanen, S., Karell, F., 2012. Palaeomagnetic and AMS studies on Satulinmaki and Koijarvi fault and shear zones. In: Gronholm, S., Karkkainen, N. (Eds.), Gold in Southern Finland; Results of GTK Studies 1998-2011. Special Paper-Geological Survey of Finland, vol. 52, pp. 195-226.

Mims, C.V.H., Powell, C.A., Ellwood, B.B., 1990. Magnetic susceptibility of rocks in the Nutbush Creek ductile shear zone, North Carolina. Tectonophysics 178 (2-4), 207-223.

Molina Garza, R.S., Geissman, J.W., Wawrzyniec, T., Weber, B., Martínez, M.L., ArandaGómez, J., 2009. An integrated magnetic and geological study of cataclasite-dominated pseudotachylytes in the Chiapas Massif, Mexico: a snapshot of stress orientation following slip. Geophys. J. Int. 177 (3), 891-912.

Ono, T., Hosomi, Y., Arai, H., Takagi, H., 2010. Comparison of petrofabrics with composite magnetic fabrics of S-C mylonite in paramagnetic granite. J. Struct. Geol. 32 (1), 2-14.

O'Reilly, W., 1984. Rock and Mineral Magnetism. Blackie, Glasgow, United Kingdom (220 pp.).

Osborn, J.A., 1945. Demagnetizing factors of the general ellipsoid. Phys. Rev. 67 (11-12), 351-357.

Owens, W.H., 1974. Mathematical model studies on factors affecting the magnetic anisotropy of deformed rocks. Tectonophysics 24, 115-131.

Owens, W.H., Bamford, D., 1976. Magnetic, seismic, and other anisotropic properties of rock fabrics. Philos. Trans. R. Soc. Lond. Ser. A Math. Phys. Sci. 283, 55-68.

Owens, W.H., Rutter, E.H., 1978. The development of magnetic susceptibility anisotropy through crystallographic preferred orientation in a calcite rock. Phys. Earth Planet. Inter. 16, 215-222.

Parés, J.M., 2004. How deformed are weakly deformed mudrocks? Insights from magnetic anisotropy. Geol. Soc. Lond., Spec. Publ. 238 (1), 191-203.

Parés, J.M., van der Pluijm, B.A., 2002. Phyllosilicate fabric characterization by lowtemperature anisotropy of magnetic susceptibility (LT-AMS). Geophysical Research Letters 29 (2215).

Parés, J.M., van der Pluijm, B.A., Dinares, T.J., 1999. Evolution of magnetic fabrics during incipient deformation of mudrocks (Pyrenees, northern Spain). Tectonophysics 307, $1-14$.

Pfiffner, A.O., Ramsay, J.G., 1982. Constraints on geological strain rates; arguments from finite strain states of naturally deformed rocks. J. Geophys. Res. 87, 311-321.

Plissart, G., Diot, H., Monnier, C., Mărunţiu, M., Berger, J., 2012. Relationship between a syntectonic granitic intrusion and a shear zone in the Southern Carpathian-Balkan area (Almăj Mountains, Romania): implications for late Variscan kinematics and Cherbelezu granitoid emplacement. J. Struct. Geol. 39, 83-102.

Poirier, J.P., 1980. Shear localization and shear instability in materials in the ductile field. J. Struct. Geol. 2, 135-142.

Poirier, J.-P., Guillopé, M., 1979. Deformation induced recrystallization of minerals. Bull. Mineral. 102, 67-74

Poirier, J., Nicolas, A., 1975. Deformation-induced recrystallization due to progressive misorientation of subgrains, with special reference to mantle peridotites. J. Geol. 707-720.

Potter, D.K., Stephenson, A., 1988. Single-domain particles in rocks and magnetic fabric analysis. Geophys. Res. Lett. 15, 1097-1100.

Ramsay, J.G., Huber, M.I., 1987. The techniques of modern structural geology. Strain Analysis, vol. 1. Academic Press, London (700 pp.).

Rathore, J.S., 1979. Magnetic susceptibility anisotropy in the Cambrian slate belt of North Wales and correlation with strain. Tectonophysics 53, 83-97.

Rathore, J.S., Courrioux, G., Choukroune, P., 1983. Study of ductile shear zones (Galicia, Spain) using texture goniometry and magnetic fabric methods. Tectonophysics 98, 87-109.

Richter, C., van der Pluijm, B.A., Housen, B.A., 1993. The quantification of crystallographic preferred orientation using magnetic anisotropy. J. Struct. Geol. 15, 113-116.

Rochette, P., 1987. Magnetic susceptibility of the rock matrix related to magnetic fabric studies. J. Struct. Geol. 9, 1015-1020.

Rochette, P., 1988. Mathematical model relationship between the paramagnetic anisotropy and strain in slates-discussion. Tectonophysics 156, 313-315.

Rochette, P., Jackson, M., Aubourg, C., 1992. Rock magnetism and the interpretation of anisotropy of magnetic susceptibility. Rev. Geophys. 30, 209-226.

Rochette, P., Scaillet, B., Guillot, S., Le Fort, P., Pêcher, A., 1994. Magnetic properties of the High Himalayan leucogranites: structural implications. Earth Planet. Sci. Lett. 126, 217-234.
Ruf, A.S., Naruk, S.J., Butler, R.F., Calderone, G.J., 1988. Strain and magnetic fabric in the Santa Catalina and Pinaleno Mountains Metamorphic Core Complex Mylonite Zones, Arizona. Tectonics 7, 235-248.

Sassier, C., Leloup, P.H., Rubatto, D., Galland, O., Yue, Y., Lin, D., 2009. Direct measurement of strain rates in ductile shear zones: a new method based on syntectonic dikes. J. Geophys. Res. B Solid Earth 114, B01406. http://dx.doi.org/10.1029/ 2008JB005597 (22 pp.).

Schulmann, K., Edel, J.-B., HasalovA, P., Cosgrove, J., Jezek, J., Lexa, O., 2009. Journal of structural geology. J. Struct. Geol. 31, 1223-1237. http://dx.doi.org/10.1016/j.jsg. 2009.07.004.

Sidman, D., Ferré, E.C., Teyssier, C., Jackson, M., 2005. Magnetic fabric and microstructure of a mylonite: example from the Bitterroot shear zone, western Montana. Geol. Soc Lond. Spec. Publ. 245, 143-163. http://dx.doi.org/10.1144/GSL.SP.2005.245.01.07.

Singh, J., Sanderson, D.J., Tarling, D.H., 1975. The magnetic susceptibility anisotropy of deformed rocks from North Cornwall, England. Tectonophysics 27, 141-153.

Stacey, F.D., 1960. Stress-induced magnetic anisotropy of rocks. Nature 188, 134-135 http://dx.doi.org/10.1038/188134a0

Stacey, F.D., Banerjee, S.K. (Eds.), 1974. The Physical Principles of Rock Magnetism. Elsevier, Amsterdam-London, Netherlands.

Stephenson, A., 1994. Distribution anisotropy: two simple models for magnetic lineation and foliation. Phys. Earth Planet. Inter. 82, 49-53.

Stipp, M., Stuenitz, H., Heilbronner, R., Schmid, S.M., 2002. The eastern Tonale fault zone: a "natural laboratory" for crystal plastic deformation of quartz over a temperature range from 250 to 700 C. J. Struct. Geol. 24, 1861-1884.

Stone, D.B., 1963. Anisotropic magnetic susceptibility measurements on a phonolite and on a folded metamorphic rock. Geophys. J. 7, 375-390 (London).

Tarling, D.H., 1971. Principles and Applications of Palaeomagnetism. Chapman \& Hall London.

Tarling, D.H., Hrouda, F., 1993. The Magnetic Anisotropy of Rocks. Chapman \& Hall, London, United Kingdom.

Tikoff, B., Greene, D., 1997. Stretching lineations in transpressional shear zones: an example from the Sierra Nevada Batholith, California. J. Struct. Geol. 19, 29-39.

Tikoff, B., Teyssier, C., 1994. Strain and fabric analyses based on porphyroclast interaction. J. Struct. Geol. 16, 477-491.

Tikoff, B., Davis, M.R., Teyssier, C., de Saint Blanquat, M., Habert, G., Morgan, S., 2005. Fabric studies within the Cascade Lake shear zone, Sierra Nevada, California. Tectonophysics 400 (1-4), 209-226.

Till, J.L., Moskowitz, B., 2013. Magnetite deformation mechanism maps for better prediction of strain partitioning. Geophys. Res. Lett. 40, 697-702. http://dx.doi.org/10.1002/ grl.50170.

Till, J.L., Jackson, M.J., Moskowitz, B.M., 2010. Remanence stability and magnetic fabric development in synthetic shear zones deformed at 500 degrees $\mathrm{C}$. Geochem. Geophys. Geosyst. 11. http://dx.doi.org/10.1029/2010GC003320.

Till, J.L., Moskowitz, B.M., Jackson, M.J., 2012. High-temperature magnetic fabric development from plastically deformed magnetite in experimental shear zones. Geophys. J. Int. 189, 229-239. http://dx.doi.org/10.1111/j.1365-246X.2011.05338.x.

Tomezzoli, R.N., MacDonald, W.D., Tickyj, H., 2003. Composite magnetic fabrics and S-C structure in granitic gneiss of Cerro de los Viejos, La Pampa province, Argentina. J. Struct. Geol. 25, 159-169.

Torsvik, T.H., Sturt, B.A., 1988. Multiphase magnetic overprints in the Moine Thrust Zone Geol. Mag. 125, 63-82.

Tripathy, N.R., Srivastava, H.B., Mamtani, M.A., 2009. Evaluation of a regional strain gradient in mylonitic quartzites from the footwall of the Main Central Thrust Zone (Garhwal Himalaya, India): inferences from finite strain and AMS analyses. J. Asian Earth Sci. 34 (1), 26-37.

Uyeda, S., Fuller, M.D., Belshe, J.C., Girdler, R.W., 1963. Anisotropy of magnetic susceptibility of rocks and minerals. J. Geophys. Res. 68, 279-291.

Vergne, R., Fernandez, A., 1990. Modèle d'anisotropie de susceptibilité magnétique induite par orientation préférentielle de forme de marqueurs paramagnétiques anisotropes dans une roche déformée. Rev. Phys. Appl. (Paris) 25 (11), 1049-1093.

Werner, T., 2002. The correlation of magnetic anisotropies (AMS and AARM) with tectonic fabrics of the Niemcza shear zone (SW Poland). Acta Geophys. Pol. 50 (1), 79-107.

Winkler, A., Florindo, F., Sagnotti, L., Sarti, G., 1996. Inverse to normal magnetic fabric transition in an upper Miocene marly sequence from Tuscany, Italy. Geophys. Res. Lett. 23, 909-912.

Wilson, J., Ferré, E.C., Lespinasse, P., 2000. Repeated tabular injection of high-level alkaline granites in the eastern Bushveld, South Africa. Journal of the Geological Society, London 17, 1077-1088.

Zavada, P., Schulmann, K., Lexa, O., Hrouda, F., Haloda, J., Týcová, P., 2009. The mechanism of flow and fabric development in mechanically anisotropic trachyte lava. J. Struct. Geol. 31 (11), 1295-1307.

Zhou, Y., Zhou, P., Wu, S.M., Shi, X.B., Zhang, J.J., 2002. Magnetic fabric study across the Ailao Shan-Red River shear zone. Tectonophysics 346, 137-150. 